\title{
НОМИНАЦИЈА ЈАБУКЕ У РЕЧНИКУ СРПСКОХРВАТСКОГА КНИЖЕВНОГ ЈЕЗИКА
}

Рад се бави различитим дериватима којима се номинује плод дрвета јабуке забележеним у Речнику српскохрватскога књижевног језика. Иако се у Речнику даје укупно 125 речи које представљају називе за јабуку, творбеној и семантичкој анализи подвргнута је 91 којој се може одредити мотиватор или особина која је довела до номинације. Међу суфиксалним дериватима најзаступљенији су, у српском језику и иначе високопродуктивни, форманти -ача и -ка, док су међу особинама које су генерисале извођење најфреквентније оне које се тичу времена дозревања плодова и њихове конзумације, те њихове боје.

Кључне речи: јабука, Речник српскохрватскога књижевног језика, суфиксални деривати, семантичко-творбена анализа.

\section{1. УВОДНЕ НАПОМЕНЕ}

1.1. Уколико се за плод неког дрвета може рећи да је дубоко укорењен у колективној свести српског народа и његовој традиционалној култури, онда је то свакако јабука: она се церемонијално дарује, пре свега будућој невести или новорођенчету, на свадби се кроз прстен гађа, нашла је своје место и у фразеологији (нпр. зелена јабука = неискусна девојка, пала ми је златна јабука у крило = оженио сам се добром девојком, горка јабука $=$ неузвраћена љубав, послати/добити јабуку = изазвати кога на двобој / прихватити позив на двобој, румен као јабука), те симболизује љубав, здравље, младост, али и мржњу и раздор. ${ }^{1}$ Сем тога, али и као последица тога, као ознака за ретко које

\footnotetext{
*ajdzanovic@ff.uns.ac.rs

** Овај рад представља део истраживања у оквиру пројекта Стандардни српски језик (178004), који финансира Министарство просвете, науке и технолошког развоја Републике Србије.

${ }^{1}$ О томе в. више у Vuksanović, 2016.
} 
воће, ${ }^{2}$ реч јабука изразито је полисемична: у Речнику српскохрватскога къижевног језика ${ }^{3}$ под овом одредницом даје се чак седам различитих значења, чиме се врло јасно показује значај јабуке у Срба. Наравно, њено посебно место није специфична одлика само овдашње културе, нити овог времена, већ јабука има и карактер општег, наднационалног симбола, о чему, између осталог, сведоче и митови старих народа, од којих је (барем у европском културном кругу) најпознатији онај о свађи међу трима грчким богињама, изазваној јабуком раздора, или пак онај старозаветни о забрањеном воћу с дрвета познања, у којем је касније препозната управо јабука. Уколико се има у виду и чињеница да данас у свету постоји чак око 7.500 сорти јабуке, и још скоро упола толико њених тзв. клонова, те да је она једна од најраспрострањенијих врста воћа, с огромним економским значајем - јасно је да овакав њен положај, барем донекле, мора бити у српском језику опредмећен и у називима који сву ту разноликост именују.

1.2. Отуд су предмет овога рада све оне мотивисане лексеме - имајући у виду горенаведено, претпостављамо сразмерно бројне - којима се у РМС означава плод те 'врсте воћке из породице ружа са много подврста', док му је циљ да забележене деривате попише, опише, те да открије особине које су послужиле као својеврсни мотивациони импулси за грађење датих изведеница. При томе, сви ће деривати бити пописани и унети у корпус, без обзира на своју провенијенцију, тј. на изворе из којих су унети у РМС, те квалификаторе који се дају уз њих.

\section{2. АНАЛИЗА}

2.1. Посебно место јабуке у српској народној култури заиста се рефлектује и у најобимнијем завршеном српском једнојезичном речнику: не рачунајући саму одредницу јабука, у њему се унутар различитих, најчешће самосталних, одредница ${ }^{4}$ даје још следећих 125 различитих лексема, чији је

\footnotetext{
${ }^{2}$ Крушка, на пример, у Речнику има два значења, док шљива има свега једно. С друге стране, ниједна од ових лексема, очекивано, нема одговарајући синоним.

${ }^{3} \mathrm{У}$ даљем тексту РМС, при чему ћемо све лексикографске дефиниције давати управо из тог речника.

${ }^{4}$ Сорта делишес, на пример, наводи се само у оквиру одреднице родитељ, а антуновка под одредницом ренет.
} 
денотат каква јабука:" авајлија, авајлика, адамовка, антоновка, бабајка, батуленка, бедрика, белина, божићница, бресквача, будимка, видовача, видовка, восковача, говеђача, голубача, делишес, дивљака, дивљакиьа, ђула, Ђулабија, железовка, жутица, зачинка, звечарка, зеленика, зимаја, зимача, зимица, зимка, зимњаја, зимњача, златара, зуква, зукваја, зуквача, иванчица, ивањача, илињача, јаблан, јабланка, јесенка, јесењача, јонатан, кабларка, кадумана, кардинал, кисељача, кићенка, клудијевка, кожара, колачара, колачарка, коњувача/коњухача, котурача, краљевић, краљицуа, крупницุа, лимунка, лимуњача, лудаја, мачанка, медењача, мекача, мекуша, мирисавка, михољьча, мушкатељка, озимача, оманка, памуклија, парадија, парменка, петровача, петровка, петровњача, питомка, погачара, попадија, поскурњача, прислина, прокупка, пртача, прутара, пругача, прутовача, прутуља, ранка, ребрача, ренет/ренета, рибњача, рузмаринка, самониклица, сенабија, сладокусан, сладокусач, слаткача, срчика, стекња, стрекиња, тамјаника, тањирача, тетанка, тетовка, тиквара, титралица, томињача, фунташица, хамајлија, циганлија, цчиганчица, црвеника, црвенка, црвенајка, црвенача, црљенка, чењача, чехњача 6 , чуњача, шареника, шербетлија, шећерлија, итедљивка, иупљика.

2.2. Ипак и наравно, нису све ове лексеме предмет нашег рада, будући да је међу њима и одређен број немотивисаних позајмљеница (нпр. делишес, Ђула, Ђулабија, јонатан, кадумана, кардинал, оманка, памуклија, парадија, ренет/ренета, сенабија, хамајлија), или оних чији нам је мотиватор, и поред јасно уочљивог форманта, непрозиран (нпр. бабајка, батуленка, клудијевка). Осим тога, с обзиром на то да су речничке дефиниције понекад крајње шкрте и опште, ${ }^{7}$ што у том случају у потпуности онемогућава идентификовање сема које су генерисале трансформацију, нећемо се бавити ни свим семантичким дериватима, који су у прикупљеној грађи сразмерно ретки. Заправо, корпус

\footnotetext{
${ }^{5}$ Иако је већ из уводних напомена сасвим јасно да неке од ових лексема имају више од једног значења, оно што можда није познато јесте да неке, не тако малобројне, међу њима нису једнореферентне ни када је у питању номинација воћа: чак њих деветнаест користи се и за именовање крушке (зимњача, илињача, јесењача, лимунка, медењача, мекуша, михољача, озимача, петровача, петровка, петровњача, питомка, тамјаника, тиквара, ирвенка, црвењача, шареника, шербетлија, итедљивка), оних за именовање грожђа има пет (зачинка, зеленика, кардинал, краљица, тамјаника), док је једна лексема чак ознака за репу (тањирача).

${ }^{6}$ Ова и претходна лексема дају се као посебне одреднице.

${ }^{7}$ Исп. нпр. стекњ $а$ 'врста јабуке'.
} 
који ћемо овог пута подвргнути било творбеној, било семантичкој анализи (а најчешће обема) чини следећи 91 дериват: адамовка, антуновка, бедрика, божићница, бресквача, будимка, видовача, видовка, восковача, говеђача, голубача, дивљака, дивљакиға, железовка, жутица, зачинка, звечарка, зеленика, зимаја, зимача, зимица, зимка, зимњаја, зимњача, златара, зукваја, зуквача, иванчица, ивањача, илињача, јабланка, јесенка, јесењача, кисељача, кићенка, кожара, колачара, колачарка, котурача, крупница, лимунка, лимуғача, медењача, мекача, мекуша, мирисавка, михољача, мушкатељка, озимача, петровача, петровка, петровъача, питомка, погачара, поскурњача, посластичарка, прокупка, пртача, пругача, прутара, прутовача, прутуља, ранка, ребрача, рибњача, рузмаринка, самониклица, сладокусан, сладокусаи, слаткача, срчика, стрекиња, тамјаника, тањирача, тетовка, титралица, томињача, фунташица, циганлија, ичиганчица, ирвеника, ирвенка, ирвењајка, ирвењача, ирљенка, чуњача, шареника, шербетлија, шећерлија, штедљивка, шупљика.

2.3. Забележени деривати изведени су укупно 21 творбеним формантом, које ћемо навести с обзиром на њихову заступљеност у грађи.

2.3.1. Мада се суфикс -ача по правилу одређује као веома продуктиван - о чему, између осталог, сведочи и Обратни речник српскога језика (Николић, 2000), у ком се наводи преко 800 лексема чији је финални сегмент ача - у свакодневној употреби, како се то у литератури на неколико места констатује (исп. нпр. Babić, 1986: 77; Клајн, 2003: 64), налази се далеко мањи број ових лексема. Међутим, у нашој грађи, с укупно 25 деривата (бресквача, видовача, говеђача, голубача, зимача, зуквача, ивањача, илињача, јесењача, кисељача, котурача, лимуғача, медењача, мекача, михољача, озимача, петровача, пртача, пругача, ребрача, слаткача, тағирача, томињача, чрвељача, чуњача), овај је суфикс најпродуктивнији.

Дати формант додаје се на глаголске, именичке и придевске основе, при чему би девербативи с обележјем [+ особа] по правилу спадали у потіna agentis, те не чуди што у нашој грађи они у потпуности изостају, док је број десупстантива (бресквача, видовача 8 , голубача, зимача, зуквача, ивағача,

\footnotetext{
${ }^{8}$ У овом примеру и онима насталим по истом моделу (ивањача, илињача, михољача, петровача, томињача), иако су придеви дефакто творбене основе, мотиватори су ипак одговарајуће редуковане именичке сложенице (нпр. Иваь[дан] + -ача > ивањача), те их и смештамо у ову групу, мада постоје и друкчија мишљења (исп. Клајн, 2003: 66).
} 
илињача, јесењача, котурача, лимуюача, михољача, петровача, пругача, ребрача, тањирача, томињача, чуюача) и деадјектива (говеђача, кисељача, медењача, мекача, озимача, пртача, слаткача, црвењача) несразмеран: наспрам седамнаест именица насталих од других именица стоји свега осам оних којима је придев мотиватор. ${ }^{9}$

Такође, како се види из примера који се обично наводе у литератури, али и из наше грађе, суфикс -ача јотује финални непалатални глас из основе, тако да Бабић заправо наводи два суфикса (-ача и -јача), за које сматра да се налазе у комплементарној дистрибуцији: други формант долази само на основе на [н], с изузетком пориулан- (Babić, 1986: 77). и И. Клајн (2003: 64), доводећи у сумњу аутономију суфикса -јача, сматра да ,jотовање делује само на -н из основе". Ипак, грађа нам показује да се, осим овог гласа, за чије јотовање заиста има највише потврда, јотује и [л] (нпр. кисељача).

2.3.2. Суфикс -ка одређује се као 'један од најважнијих именичких суфикса у словенским језицима', који у српском језику, пре свега због своје знатно редуковане деминутивне функције, има осетно ужу употребу него у источнословенским и западнословенским језицима (Клајн, 2003: 131). Ово, наравно, не значи да он у српском језику није продуктиван, напротив: у Николић, 2000 даје се око 5.000 речи на -ка, од којих највећи део чине управо семантички разноврсне лексеме деривиране овим суфиксом, или неким од њиме сложених суфикса. Отуд не чуди и његова продуктивност у именовању плода јабуке, где је њиме деривирано двадесет назива (адамовка, антуновка, будимка, видовка, зачинка, зимка, јабланка, јесенка, кићенка, лимунка, мирисавка, петровка, питомка, прокупка, ранка, рузмаринка, тетовка, црвенка, црљенка, итедљивка).

Иако И. Клајн (2003: 134) наводи да се овај формант додаје на различите врсте речи, при чему се за придеве везује скоро само по изузетку, у нашем корпусу налази се чак девет деадјектива (адамовка, антуновка, кићенка, мирисавка, питомка, ранка, црвенка, црљенка, итедљивка). Дати деривати настали су везивањем форманта за присвојни (Адамов, Антунов)

\footnotetext{
${ }^{9}$ Наравно, под условом да смо овде, а и ниже у раду, правилно одредили мотиваторе, будући да се, због значењског и обличког поклапања, те честих лапидарних речничких дефиниција, понегде може говорити о двострукој мотивацији, тј. могућности да се и придев и именица истовремено нађу у датој улози (исп. нпр. сасвим оправдану недоумицу у вези с одређивањем мотиватора: зима/зим[ски] + -ача > зимача).
} 
односно описни (мирисав, питом, ран, црвен/црљен, итедљив), или чак трпни придев (кићен). Преосталих једанаест деривата по пореклу су десупстантиви (будимка, видовка, зачинка, зимка, јабланка, јесенка, лимунка, петровка, прокупка, рузмаринка, тетовка), од којих су два, попут горенаведених примера, настала од редуковане именичке композите чији се остатак поклапа с присвојним придевом (Видов[дан] + -ка > видовка, Петров $[\partial а н]+-к а>$ петровка).

2.3.3. Суфикс -ика, како то И. Клајн (2003: 88-90) наводи, само је наизглед продуктиван, будући да већина, иначе бројних, речи деривираних њиме спада у пасивни фонд српског језика, при чему највећи део представља управо фитониме. Без обзира на потоње написано, међутим, овај формант у нашој грађи регистрован је у свега седам деривата (бедрика, зеленика, срчика, тамјаника, црвеника, шареника, шупљика), при чему се јасно показује дистрибутивна особина тог суфикса, који се најчешће додаје на придевске и именичке основе: десупстантива има три (бедрика, срчика, тамјаника), а деадјектива четири (зеленика, црвеника, шареника, шупљика). Занимљиво је да се од забележених деривата само тамјаника наводи у Клајн, 2003.

2.3.4. Иако је суфикс -ица један од најпродуктивнијих суфикса уопште у српском/хрватском језику (исп. нпр. Стевановић, 1964: 551; Babić, 1986: 135; Клајн, 2003: 113), наш корпус садржи свега пет лексема њиме деривираних

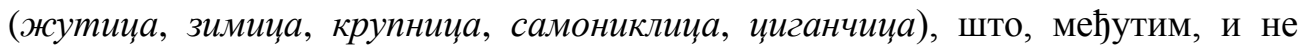
треба да чуди, с обзиром на то да су његове две основне функције, у којима се јавља чешће од иједног другог суфикса (Клајн, 2003: 115-116), деминутивна и моциона. Ипак, чак је и у овако ограниченом узорку прва од наведених функција потврђена (циганчица), при чему остатак чине још један десупстантив (зимица) и три деадјектива (жутищуа, крупница, самониклица).

2.3.5. Исти број потврда у грађи има и -ара (златара, кожара, колачара, погачара, прутара), продуктивни суфикс који се додаје пре свега на именичке и глаголске основе, док се са придевским ретко везује (Клајн, 2003: 47). Последње показују и наши примери: свих пет деривата јесу десупстантиви. Занимљиво је да И. Клајн (2003: 47-50) међу семантички диверсификованим дериватима добијеним овим суфиксом не наводи ниједан којим би се означио плод јабуке, па чак ни било ког другог воћа.

2.3.6. Суфикс -њача настао је перинтеграцијом, те, иако је у речницима потврђен у мноштву речи, скоро без изузетка десупстантива и деадјектива, оних које су општепознате и у свакодневној употреби - знатно је мање (Клајн, 2003: 67). У складу с тим јесте и стање из наше грађе: (свега) 
четири деривата изведена су датим суфиксом (зимьача, петровњача, поскурњача, рибњача). Ипак, оно што га издваја у односу на остале суфиксе којима се изводе називи за јабуку јесте његова дистрибуција: дати деривати добијени су додавањем суфикса на именице (зимњача ${ }^{10}$, поскурњача ${ }^{11}$ ), чак и редуковане (петровњача), те, што је нарочито занимљиво, глаголе (рибњача). Наиме, у литератури се као девербативи изведени овим суфиксом наводе само хладњача, упртьача и напртьвача (Клајн, 2003: 67).

2.3.7. Међу преосталих петнаест суфикса, три су послужила за грађење по трију лексема: -аја (зима + -аја > зимаја, зимьи + -аја > зимьаја, ${ }^{12}$ зуква + аја > зукваја), -а̄рка (звечарка, колачарка, посластичарка) и -лија (циганлија, шербетлија, шећерлија), међу којима је само један дериват добијен од глаголске основе (звеч[amu] + -аррка), док су остали (несумњиви?) десупстантиви.

У вези са суфиксом -арка ваљало би рећи да се он пре свега (понеко би рекао искључиво, исп. нпр. Клајн, 2003: 139) везује за именице, те да није продуктиван; међутим, како видимо, један од забележених деривата, и иначе општепознат, добијен је од глаголске основе.

Ипак, нарочито је занимљив формант -лија - добијен од турског -li, које је придевског порекла (Клајн, 2003: 145) - који се 'никада није спајао са чисто домаћим основама, него само са одомаћеним турцизмима или другим именицама страног порекла', што је случај и у двама од трију забележених деривата. Међутим, и овде се могу јавити недоумице: ту се може радити о поимениченим адаптираним турским придевима (тур. şekerli, şerbetli) или о додавању адаптираног турског суфикса, умерено продуктивног у српском језику, на већ одомаћене турцизме шећер и шербет (тур. şeker, şerbet), чему бисмо и дали предност, с обзиром на горенаведено запажање И. Клајна.

2.3.8. Два суфикса пак идентификована су у по двема лексемама. Први је -иња, потврђен у дериватима дивљакиња и стрекиња, насталим такође од

\footnotetext{
10 Иако би овде дефиниција дата у РМС ('зимска јабука, крушка') дала предност идентификовању придева као мотиватора, а тиме и другог суфикса (-ача), предност ћемо због облика дати именици.

11 Поскура је 'обредни хлеб у православној литургији, нафора'.

${ }^{12}$ Ни И. Клајн ни С. Бабић у својим монографијама не дају евентуални суфикс *-њаја, те смо овде принуђени да као мотиватор идентификујемо дати придев.
} 
именичке основе (дивљак + -иња, ${ }^{13}$ стрека $^{14}+-$-иња), док је други сложени формант -овача, чија се самосталност понекад доводи у питање (исп. нпр. Клајн, 2003: 66). Наиме, у већини деривата који се наводе као илустрација за постојање датог суфикса може се као мотиватор идентификовати и одговарајући присвојни придев, на који је додат суфикс -ача. Ипак, у дериватима восковача и прутовача, како због значења ${ }^{15}$ тако и због нефреквентних облика придева восков, - $a$, -о и прутов, - $a$, -о - предност као мотиватору даћемо именици.

2.3.9. Коначно, скоро половина свих забележених суфикса (десет) идентификована је само у по једном деривату (црвен + -а̄јка > црвењајка; диваљ + -ака > дивљака; фунта + -ашица > фунташица; мушкат + -ељка > мушкатељка; титра[ти] + -лица > титралицуа; Божић + -ница > божићница; железо + -овка > железовка; пруm + -уља > прутуља; мек + -уша $>$ мекуша; Иван[дан] + -чица > иванчица), међу којима су пре свега присутни десупстантиви (шест), али и деадјективи (три), па чак и један девербатив.

Поједини међу забележеним дериватима и формантима захтевају краћи осврт. Први такав јесте суфикс -ајка, за који И. Клајн (2003: 138) наводи свега три потврде, међу којима нема деривата регистрованог у грађи (љуљајка, тоциљьјка, шевељајка). С друге стране, дивљака се даје у Клајн, 2003: 16 као једина потврда за јединачни суфикс -ака. Такође, као један од ретких примера у којима је дериват на -чица недеминутивно образовање, у Клајн, 2003: 124 наводи се управо иванчициа.

2.3.10. На самом крају овог дела анализе ваљало би поменути и лексеме сладокусан и сладокусац, које се издвајају међу осталима у прикупљеном корпусу. Наиме, прва је једини пример конверзије: из категорије придева прешла је у именице, док је друга једина композита, настала сложено-суфиксалном творбом (слад-о-кус-ац).

${ }^{13}$ С обзиром на значење овог фитонима ('дивља јабука'), овде би се пре могао идентификовати суфикс *-акињ $а$, који се, међутим, као самосталан не даје ни у Клајн, 2003 ни у Babić, 1986.

${ }^{14}$ У РМС стрека се одређује као 'издужен, узан део нечега на каквој површини, трака', док је стрекињ $а$ 'врста пругасте јабуке'.

15 Восковача је 'врста јабуке и шљиве које имају боју сличну воску', док је прутовача 'врста црвено испрутане јабуке'. 
2.4. Када су у питању особине јабуке које су послужиле за њено именовање, анализу ћемо извршити само на оним дериватима код којих је јасан механизам који је довео до номинације.

2.4.1. Међу оваквим називима својом се бројношћу - с обзиром на основну намену јабуке, рекли бисмо посве очекивано - издвајају они који се тичу времена када јабука дозрева, тј. када се може конзумирати; укупно их је двадесет (видовача, видовка, зимаја, зимача, зимица, зимка, зимюаја, зимьача, иванчица, ивањача, илињача, јесенка, јесењача, михољача, озимача, петровача, петровка, петровњача, ранка, томињача). Њихови су мотиватори најчешће имена годишњих доба (тј., непосредно, придеви њима мотивисани) или значајнијих верских празника (Петровдан, Ивањдан, Илиндан, Михољдан, Томиндан). На први поглед, потоњим би припадао и назив божићница; међутим, како показује лексикографска дефиниција у $\mathrm{PMC}^{16}$ и у прикупљеној грађи јединствени квалификатор етн., дериват је мотивисан њеном наменом, тј. обичајном улогом коју јабука има, а не временом када доспева или се конзумира.

2.4.2. Следећу групу, незнатно малобројнију од претходне (осамнаест), чине деривати чији је настанак мотивисан бојом плода или шарама на њему (белина, жутица, зеленика, златара, лимунка, лимуњача, пругача, прутара, прутовача, прутуља, ребрача, стрекиња $a^{17}$, црвеника, црвенка, црвеюајка, црвењача, црљенка, шареника), при чему је међу њима, када је у питању боја, посве разумљиво, највише речи којима се означава плод црвене боје, који је, без обзира на сву постојећу разноврсност, рекли бисмо, и даље прототип целог рода Malus.

2.4.3. Помало неочекивано, међутим, тек на треће место долазе особине које се тичу укуса плода: свега је шест деривата унутар дате подгрупе (кисељача, медењача, сладокусаи, сладокусан, шербетлија, шећерлија). Ипак, с друге стране, сасвим је предвидљива чињеница да се чак пет међу њима користи као ознака за јабуку пожељног, слатког укуса, док је само кисељача ознака за друкчији плод.

2.4.4. Шест деривата налазимо и унутар подгрупе коју чине називи мотивисани наменом и употребом јабуке (божићница, колачара, колачарка, поскуръача, посластичарка, титралица). Међутим, иако сразмерно

\footnotetext{
${ }^{16}$ Божићница је '1. јабука која се поклања о Божићу. 2. јабука коју младожења даје девојци кад жели да му постане заручница'.

${ }^{17}$ Стрекаст 'пругаст'.
} 
малобројна, ова је скупина посве илустративна када је у питању место јабуке у српској традиционалној култури: плод, као што смо видели, служи не само за јело, тј. припремање посластица (колачара, колачарка, посластичарка), већ има јасно место и у народним обичајима (божићница, поскурњача) и играма (титралиц̧а).

2.4.5. По четири деривата служе као називи мотивисани обликом (котурача, погачара, тањирача, чуњача), начином раста биљке (дивљака, дивљакиња, питомка, самониклица), те каквоћом (мекача, мекуиа, срчика, иупљика) и величином њеног плода (крупниц̧а, фунташицуа, цчиганлија, цุиганчицуа), док је трима означено порекло сорте (будимка, прокупка, тетовка), односно мирис, без изузетка пријатан, који плод одаје (мирисавка, мушкатељка, тамјаника). Међу датим називима посебно су занимљиви цุиганлија и цчиганчицฺа, ${ }^{18}$ по свој прилици истозначни, будући да нам није најјасније која је колективна стереотипна представа о Ромима послужила за грађење назива.

2.4.6. Коначно, особина која је послужила за грађење најмањег броја деривата јесте каквоћа коре (восковача, кожара), што може бити индикативно када је у питању хијерархија пожељних особина јабуке у Срба.

\section{3. ЗАКљУЧАК}

3.1. На самом крају можемо закључити да је значај који јабука има у српској народној култури, и не само у њој, јасно видљив и у оном сегменту српског лексикона забележеном у РМС: чак 91 мотивисани назив за ово воће био је предмет наше анализе. Највећим делом у питању су суфиксални деривати добијени додавањем суфикса на именичке (59) или придевске (27) основе, док су остали начини творбе и мотиватори присутни само по изузетку, што је очекивана дистрибуција када је у питању врста како мотиватора тако и творбених поступака. Оно што је занимљиво, међутим, јесте да многе лексеме, по свој прилици, представљају творбене дублете, нарочито када су у питању оне које означавају јабуке које доспевају о неком празнику или имају одређену боју (исп. нпр. петровача, петровка, петровьача; црвеника, црвенка, црвењајка, црвенача, црљенка), те да у Клајн, 2003 немају потврду, или представљају крајње ретке или чак нерегистроване творбене моделе.

\footnotetext{
18 Док се цииганлија одређује као 'врста црвене ситне јабуке', цицанчища је 'врста ситне јабуке мрко-црвене боје'.
} 
3.2. Када су у питању особине које су послужиле за именовање јабуке, на прво место долазе оне које говоре о ономе што је за човека и најважније: о времену када јабука дозрева, а потом о њеном изгледу, пре свега боји, те о облику и укусу. Занимљиво је да, док се приликом именовања какве особе у српском језику $^{19}$ у први план стављају особине које на неки начин представљају отклон од очекиваног, пожељног стања - дакле, предност се даје негативним етикетама, које се граде читавим низом форманата и творбених модела - код номинације јабуке, а претпостављамо да исто важи и за плодове другог воћа, ситуација је управо обратна: оне особине које су пожељне јесу оне које најчешће генеришу номинацију, док оне негативне то чине само по изузетку.

3.3. Коначно, још једна занимљивост: иако, дакле, постоји читаво богатство назива за различите сорте јабуке, те иако је сама реч јабука изразито семантички диверсификована, њен је деривациони потенцијал сразмерно скроман, те број деривата није у суодносу са тим богатством значења: у РМС даје се укупно 21 лексема чији је мотиватор ова реч, при чему су, без изузетка, у питању првостепени и другостепени суфиксални деривати (јабуков, јабуковач, јабуковача, јабуковик, јабуковина, јабучар, јабучара, јабучарица, јабучарка, јабучаров/јабучарев, јабучаст, јабучетина, јабучик, јабучина, јабучић, јабучииа, јабучји, јабучни, јабучница, јабучњача, јабучњак).

Milan S. Ajdžanović

NOMINATION OF THE APPLE IN A DICTIONARY OF THE SERBO-CROATIAN LITERARY LANGUAGE

\section{Summary}

This paper examines derivated nouns denoting apples that are found in the six-volume Dictionary of Serbo-Croatian Literary Language by Matica srpska and Matica hrvatska. The analysis shows that the nouns in question are rather abundant - there are as many as 91 of them - which clearly shows the importance of apples in Serbian traditional culture. Furthermore, the nouns are derived with a significant number of different suffixes (21), among which the most productive are -ača and -ka, two highly productive suffixes in Serbian word formation. Also, when it comes to traits which gave rise to nominating apples,

${ }^{19}$ И не само у њему, већ, како се чини, и у сваком другом (исп. Драгићевић, 2001; Ајџановић, 2007; Штасни, 2013). 
the most productive are those which are positive, concern the season of ripening and harvest, and the colour of apples.

Key words: apple, Dictionary of Serbo-Croatian Literary Language, suffixial derivatives, semantic-derivative analysis

\section{ЛИТЕРАТУРА}

Ajdžanović, M. (2008). Funkcionalno opterećenje sufiksa za obeležavanje osoba. Novi Sad: Filozofski fakultet. (knjiga objavljena na ćirilici)

Babić, S. (1986). Tvorba riječi u hrvatskom književnom jeziku (Nacrt za gramatiku). Zagreb: ČGP Delo.

Dragićević, R. (2001). Pridevi sa značenjem ljudskih osobina u savremenom srpskom jeziku (Tvorbena i semantička analiza). Beograd: Institut za srpski jezik SANU. (knjiga objavljena na ćirilici)

Klajn, I. (2003). Tvorba reči u savremenom srpskom jeziku, Drugi deo, Sufiksacija i konverzija. Beograd: Zavod za udžbenike i nastavna sredstva - Institut za srpski jezik SANU. Novi Sad: Matica srpska. (knjiga objavljena na ćirilici)

Nikolić, M. (2000). Obratni rečnik srpskoga jezika. Beograd: Institut za srpski jezik SANU - Palčić. Novi Sad: Matica srpska. (knjiga objavljena na ćirilici)

Rečnik srpskohrvatskoga književnog jezika (1967-1976). Novi Sad: Matica srpska. Zagreb: Matica hrvatska. (rečnik objavljen na ćirilici)

Stevanović, M. (1964). Savremeni srpskohrvatski jezik (Gramatički sistemi $i$ književnojezička norma) I. Beograd: Naučno delo. (knjiga objavljena na ćirilici)

Štasni, G. (2013). Reči o čoveku (nominacija čoveka u srpskom jeziku). Novi Sad: Filozofski fakultet. (knjiga objavljena na ćirilici)

Vuksanović, R. (2016). Simbolika jabuke u srpskoj tradicionalnoj kulturi. Politika. Preuzeto sa http://www.politika.rs/sr/clanak/369804/Simbolika-jabuke-usrpskoj-tradicionalnoj-kulturi 
СРПСКА КЬИЖЕВНОСТ 
